\title{
Merenkulun valtiontukien strateginen legitimointi
}

\author{
Katriina Lehto \& Eija Vinnari
}

\section{ABSTRACT \\ Strategic legitimation of state shipping subsidies}

Our purpose was to identify strategies through which different actors construct the legitimacy of state subsidies to shipping. To this end, we analysed documents and interviews using Critical Discourse Analysis. Five discourses were identified as legitimating state shipping subsidies: preventing outflagging, securing employment, maintaining logistical routes and security of supply, promoting tourism, and guaranteeing conformity among EU countries. To conclude, shipping subsidies have a legitimate position among the most important decision-making stakeholder groups in Finland, which ensures the stability and continuity of the subsidizing.

Keywords: state subsidies, shipping, legitimacy, discourse analysis

\section{JOHDANTO}

Valtion puuttuminen markkinoiden toimintaan on ollut kiistelty aihe taloustieteiden alalla jo vuosisatojen ajan. Eräs tapa, jolla valtio voi puuttua markkinoiden toimintaan, on valtiontukien myöntäminen. Valtiontuet kiinnostavat myös julkisen talousjohtamisen tutkimuksessa, sillä ne muodostavat huomattavan osuuden julkisten varojen käytöstä. Suomessa valtiontukien kokonaismäärä oli vuonna 2015 noin 1,7 miljardia euroa (Tilastokeskus 2017). Nykyisen lainsäädännön mukaan valtiontuiksi luetaan suorien tukien ja verotukien lisäksi myös avustukset ja korkotuet sekä sellaiset lainat, takaukset, takuut, oman pääoman ehtoiset rahoitukset ja muut järjestelyt, jotka sisältävät taloudellista tukea (Laki taloudelliseen toimintaan myön- nettävän tuen yleisistä edellytyksistä 429/2016). Suomalainen valtiontukilainsäädäntö on vahvasti kytköksissä Euroopan Unionin lainsäädäntöön. Valtiontukien keskeisimmät perusteet antaa sopimus Euroopan Unionin toiminnasta (EUT), artiklat 107-109, joissa määritellään Unionin sisämarkkinoille soveltuvat ja kielletyt valtiontuet.

Valtiontukien vaikuttavuuden arviointi on vaikeaa, sillä tuetun yrityksen kehitystä ilman tukea ei voida havainnoida eikä ulkoisvaikutuksia tai tukien mahdollisia haitallisia vaikutuksia markkinoiden toimintaan pystytä tunnistamaan tai mittaamaan luotettavasti (Rauhanen ym. 2015). Yleisen periaatteen mukaisesti valtiontukien tulisi perustua markkinahäiriön korjaamiseen, eivätkä terveet ja markkinakelpoiset yritykset yleensä tarvitse tukia. Ollakseen tehokkaita valtiontukien tulisi olla väliaikaisia ja niiden tulisi korjata markkinoiden toimimattomuutta. Tästä huolimatta valtaosa tuista kohdentuu suurehkojen ja vakiintuneiden yritysten toiminnan pitkäaikaiseen tukemiseen (Koski \& Ylä-Anttila 2011).

Aiemmassa tutkimuksessa valtiontukia on tutkittu talousteoreettisesta näkökulmasta eli on keskitytty mallintamaan tukien vaikuttavuutta ja muita taloudellisia vaikutuksia. Sen sijaan vähemmän huomiota on kiinnitetty siihen, minkälaisilla strategioilla pyritään luomaan käsityksiä tukien yhteiskunnallisesta hyväksyttävyydestä eli legitimiteetistä. Legitimiteetillä tarkoitetaan yleisluontoista käsitystä siitä, että jonkin käytänteen tai organisaation olemassaolo ja toiminta ovat yleisesti hyväksyttyjä ja linjassa sosiaalisesti konstruoitujen normien, arvojen, uskomusten ja määritelmien kanssa (Suchman 1995). Tässä tutkimuksessa legitimiteetin rakentumista tutkitaan kriittisen diskurssianalyysin keinoin. Diskurssi on monitulkintainen käsite, mutta tässä tutkimuksessa näemme sen 
Faircloughia (1992) mukaillen koostuvan tekstistä, sen tulkintaprosessista sekä institutionaalisesta kontekstista. Diskurssianalyysillä puolestaan tarkoitamme tekstien ja puheen kautta rakentuvien merkitysten tarkastelua suhteessa siihen yhteiskunnalliseen kontekstiin, jossa ne on tuotettu.

Valtiontukien legitimoinnin tutkiminen lisää ymmärrystä niistä kielellisistä strategioista, joiden avulla valtiontuista luodaan hyväksyttävä ja tarpeellinen kuva ja joiden avulla niiden olemassaolo perustellaan. Legitimiteetin rakentumisen tutkiminen antaa mielenkiintoisen näkökulman muun muassa poliittisen päätöksentekoon ja edunvalvontajärjestelmän toimintaan. Kielellisten strategioiden avulla tapahtuvan legitimoinnin tutkiminen pyrkii osoittamaan, että valtiontukien olemassaolon välttämättömyys ei ole absoluuttinen tosiasia, vaan ihmisten kommunikaation välityksellä rakentunut käsitys todellisuudesta. Tämän tutkimuksen tiedonintressi on tulkitseva mutta samalla tutkimus on myös kriittinen, ja sillä on emansipatorinen tavoite tuottaa tietoa yhteiskunnan sisäänrakennetuista ja usein tiedostamattomista valtarakenteista sekä niistä vapautumisesta.

Tämän tutkimuksen tapauksena tutkitaan merenkulun valtiontukia. Merenkulun valtiontuet ovat erilaisia muihin yritystukiin verrattuna, sillä ne ovat pysyviä ja kohdistuvat tuettavien yritysten liiketaloudelliseen perustoimintaan (ks. VTV 2013; VTV 2015). Merenkulkuelinkeinon tuensaajat ovat Suomen suurimpien yritystukien vastaanottajien joukossa (YLE 2015), jolloin kyse on merkittävästä julkisen sektorin varainkäytöstä. Merenkulun tukiin liittyy myös kohdentumisongelma, joka tekee niistä erityisen mielenkiintoisen tutkimuskohteen. Merenkulun tukia myönnetään Suomessa sekä rahti- että matkustaja-aluksille. Tuilla on mahdollisuus kohdentua myös vapaa-ajalla tapahtuvan turismiin ja laivamatkailuun, sillä meriliikenteessä toimii useita matkustaja-autolauttoja, jotka kuljettavat sekä rahtia että matkustajia. Pelkästään matkustajamerenkulkuun kohdistuu arvioiden mukaan noin 241-255 miljoonaa euroa merenkulun kokonaistukipotista vuosittain (Lehto ym. 2017). Merenkulun tuet eivät siis allokoidu pelkästään yhteiskunnan kannalta hyödyllisiin toimintoihin, kuten esimerkiksi logististen reittien ylläpitoon ja huoltovarmuuden ${ }^{1}$ turvaamiseen, vaan myös vapaa-ajan matkailun tukemiseen.

Merenkulun valtiontukien kohdentumisen problematiikan vuoksi aihetta on mielenkiintoista lähestyä legitimiteetin eli yleisen hyväksyttävyyden näkökulmasta. Tässä tutkimuksessa ollaan erityisen kiinnostuneita niistä strategioista, joiden avulla toimijat luovat käsityksen valtiontuen legitiimistä olemuksesta sekä siitä, millaisiin legitimiteetin muotoihin valtiontukien oikeutuksen ymmärretään perustuvan. Tutkimuskysymykset ovat seuraavat: Millaisilla strategioilla merenkulun tukia legitimoidaan? Millaiseen legitimiteettiperustaan vetoamalla merenkulun valtiontukien oikeutusta perustellaan?

Ensimmäinen valtiontukien legitimointiin liittyvä tutkimuskysymys keskittyy ymmärtämään legitimiteetin rakentumista. Valtiontuen legitimiteettiä eli mielikuvaa tuen hyväksyttävyydestä rakennetaan kielellisin keinoin puheiden ja tekstien tasolla. Legitimiteetin rakentumista tutkitaan legitimointistrategioiden teorian avulla, jolla tarkoitetaan tässä tutkimuksessa Van Leeuwenin (2008) sekä Vaaran ym. (2006) tunnistamia legitimointistrategioita: auktorisointi, rationalisointi, moralisointi, narrativisointi ja normalisointi. Ensimmäisessä tutkimuskysymyksessä nostetaan esille legitimiteetin rakentumisen diskursiivinen luonne ja siihen liittyvät kielelliset strategiat.

Toisen tutkimuskysymyksen avulla pyritään ymmärtämään, minkälaiseen legitimiteettiperustaan vetoamalla valtiontukien oikeutus perustellaan. Toinen tutkimuskysymys perustuu valtiontukien koettuun oikeutukseen, millä tarkoitetaan käsitystä siitä, miksi tukien olemassaolo koetaan oikeutetuksi ja hyödyttäväksi. Legitimiteettiperustan määritelmänä käytetään Suchmanin (1995) teoriaa legitimiteettityypeistä, jotka ovat pragmaattinen, moraalinen ja kognitiivinen legitimiteettityyppi. Sekä ensimmäisessä että toisessa tutkimuskysymyksessä tutkitaan sekä valtion että tuensaajien eli varustamojen puhetta ja tekstejä, jolloin legitimiteetin rakentumisesta ja perusteista saadaan tietoa kahden eri tahon näkökulmasta.

Tutkittaessa legitimiteetin rakentumista huomio kiinnitetään kieleen ja sen luomaan todellisuuteen. Tässä tutkimuksessa tiedon luonne käsitetään sosiaalisesti konstruoituneeksi eli nähdään, että toimijat luovat ja rakentavat ilmiöitä 
samanaikaisesti niistä viestiessään. Kuvaukset maailmasta ovat puhujansa reflektioita todellisuudesta, eikä täten mikään kuvaus ole toista parempi tai oikeampi. Sosiaalisen konstruktivismin kokonaisvaltaisuudesta on kuitenkin eriäväisiä käsityksiä. Faircloughin (2003) mukaan todellisuus tulee nähdä osittain sosiaalisesti konstruoituneena. Äärimmilleen vietynä sosiaalinen konstruktivismi tarkoittaisi sitä, että joka hetki maailmaa ja tietoa rakennettaisiin uudelleen nollapisteestä. Oleellisempaa on kuitenkin ajatella todellisuutta vain osittain sosiaalisesti konstruoituneena, sillä maailmassa on olemassa jo aikaisemmin rakentuneita realiteetteja, jotka tuovat rajoitteita ja vaikutuksia tämänhetkisiin diskursseihin. Sosiaalisen konstruktivismin näkökulma auttaa ymmärtämään sen, että tutkimuksessa käsiteltävät argumentit ja perusteet ovat eri toimijoiden käsityksiä valtiontukien olemassaolon tärkeydestä, eivät absoluuttisia totuuksia.

\section{LEGITIMITEETTITYYPIT JA LEGITIMOINNIN STRATEGIAT}

Legitimiteetti voidaan käsitteenä jakaa normatiiviseen ja empiiriseen legitimiteettiin. Normatiivinen legitimiteettitutkimus on kiinnostunut instituutioiden auktoriteetin oikeutuksesta (rightfulness) ja hyväksyttävyydestä, jotka perustuvat demokratian ja oikeudenmukaisuuden kaltaisille normatiivisille kriteereille. Normatiivisessa legitimiteettitutkimuksessa ollaan kiinnostuneita siitä, täyttävätkö tutkimuksen kohteena olevat instituutiot ennalta määritellyt legitimiteetin kriteerit. (Gronau \& Schmidke 2016.) Käsillä oleva tutkimus nojaa kuitenkin empiiriseen tutkimusperinteeseen, jonka mukaisesti legitimiteetti nähdään sosiaalisesti konstruoituvana ja suhteellisena ilmiönä.

Suchman (1995) jakaa legitimiteetin kolmeen eri osaan: pragmaattiseen, moraaliseen ja kognitiiviseen legitimiteettiin. Pragmaattisessa mielessä organisaation legitimiteetti rakentuu sen toiminnan tuotoksille tai sen kautta saadulle vaikutusvallalle. Pragmaattisen legitimiteetin keskiössä on sidosryhmien oman edun tavoittelu, jolloin legitimiteettiä muodostuu organisaation lähimpien sidosryhmien piirissä. Moraalisesta näkökulmasta organisaatio puolestaan on legitiimi, kun se edistää moraalisesti oikeita asioita kuten yleistä hyvinvointia tai tasa-arvoa. Kognitiivinen legitimiteetti puolestaan tarkoittaa syvällistä ja tiedostamatonta hyväksyntää, joka pohjautuu itsestäänselvyyksiin, oletuksiin sekä hiljaisesti hyväksyttyihin toimintatapoihin.

Koska legitimiteetti on organisaation elinehto, organisaatiot käyttävät erilaisia strategioita legitimiteettinsä rakentamiseen, ylläpitämiseen ja korjaamiseen (Suchman 1995, 586-597). Diskurssianalyyttisestä näkökulmasta Vaara ym. $(2006,793)$ määrittelevät legitimointistrategioiden olevan tapoja, joilla kieltä käytetään legitimiteetin konstruoimiseen. Joutsenvirran ja Vaaran $(2015,744)$ määritelmän mukaan legitimointistrategiat ovat diskursiivisia prosesseja, joiden kautta teksteissä tai sosiaalisissa konteksteissa luodaan mielikuvia legitiimeistä tai ei-legitiimeistä asioista tai toimintatavoista. Vaaran ym. $(2006,794)$ mukaan soveltamalla legitimointistrategioita ja analysoimalla tekstejä kriittisen diskurssianalyysin näkökulmasta saadaan tietoa organisaation kompleksisuudesta, monitulkintaisuudesta sekä sen legitimiteetin ristiriidoista, jotka jäävät usein huomaamatta perinteisempiä tutkimusmetodeja käytettäessä.

Legitimointistrategioiden tutkimuksessa viitataan usein Van Leeuwenin ja Wodakin (1999) sekä Van Leeuwenin (2008) luokitteluun, joka koostuu neljästä tyypillisestä legitimointistrategiasta: auktorisointi, rationalisointi, moralisointi sekä narrativisointi. Myöhemmin Vaara ym. (2006) ovat lisänneet tähän luokitteluun viidennen legitimointistrategian, normalisoinnin.

Auktorisoinnilla tarkoitetaan jonkin toiminnan oikeutuksen perustelua auktoriteetin avulla (Van Leeuwen 2008). Auktorisoinnin keinoja ovat perinteeseen, tapaan, lakiin tai vaikutusvaltaisiin henkilöihin vetoaminen ylempänä auktoriteettina. Nämä toimijat eivät tarvitse muunlaista oikeutusta toimilleen kuin statuksen ja siitä kumpuavan auktoriteettiaseman, esimerkiksi esimieheltä otetaan vastaan työmääräyksiä hänen auktoriteettiasemansa vuoksi. Auktorisointi voi tapahtua myös persoonattomasti, jolloin vedotaan muun muassa lakeihin, sääntöihin ja ohjeisiin. Nykyisessä yhteiskunnassa persoonatonta auktoriteettia voivat edustaa esimerkiksi markkinat, jolloin niille annetaan ihmisen kaltaisia ominaisuuksia, kuten taidot "arvioida" ja "pelätä" tilanteita (Vaara ym. 2006, 799). Julkiset toimijat puolestaan saavat auktoriteettiaseman- 
sa siitä, että he eivät toimi pelkästään oman agendansa mukaan, vaan myös kansalaisten puolesta (Reshef \& Keim 2014).

Rationalisointistrategian keinoin vedotaan legitimoitavan asian hyötyyn tai tarkoitukseen eli toivottuihin päämääriin (Van Leeuwen 2008, 113-115). Nämä hyödyt voivat olla hyvin konkreettisia, kuten talouskasvu, skaalaedut, tehokkuus tai osakkeiden arvonnousu (Vaara ym. 2006, 800). Rationalisointia käytettäessä vedotaan yleisesti siihen, että toivottujen määränpäiden saavuttamiseksi ei ole mitään muuta vaihtoehtoa kuin se, mitä esitetään. Usein rationalisoinnin keinoin argumentoidessa häivytetään mahdollisten vaihtoehtoisten polkujen seuraaminen (Reshef \& Keim 2014).

Moralisointi legitimointistrategiana perustuu arvoihin. Yksinkertaisimmillaan arvokeskustelu käsittää hyvän ja pahan, mutta useassa tapauksessa arvoihin viitataan hienovaraisesti muiden termien kautta. Adjektiiveihin terveellinen, oikeudenmukainen ja hyödyllinen on esimerkiksi sisäisesti rakentunut viittaus hyvään moraaliin. Diskurssianalyysin keinoin moralisointi voidaan tunnistaa, mutta laajempaan analyysiin siitä, miksi jotkin arvot koetaan hyvän moraalikäsityksen mukaiseksi, ei voida diskurssianalyysin keinoin vastata (Van Leeuwen 2008, 109-110). Moralisoinnin legitimointistrategia tulee teksteissä esille usein hienovaraisesti, eikä suoraa moralisointia esiinny kuin harvoin. Moralisointia esiintyy kuitenkin viittauksissa arvojärjestelmiin, kuten nationalismiin ja humanismiin. Arvojärjestelmien kautta moralisoidessa puututaan ilmenneisiin ongelmakohtiin vaihtoehtoisiin ideologioihin vetoamalla, esimerkiksi nationalismin kautta oman maan etujen mahdolliseen menettämiseen (Vaara ym. 2006, 801).

Moralisoinnin ja rationalisoinnin legitimointistrategiat esiintyvät yleisesti samanaikaisesti, jopa siinä määrin, että Vaaran ym. (2006) mukaan on kyseenalaista, muodostavatko ne lopulta kaksi erillistä kategoriaa. Kaikki rationalisoinnit perustuvat moraaliin ja ideologioihin, eikä rationalisointia voi olla olemassa ilman moraalista perustaa. Moralisoinnin legitimointistrategian avulla voidaan huomio kuitenkin kiinnittää syvällisemmin arvo- ja ideologiakeskusteluun kuin rationalisoinnin kautta. Rationalisointi voidaan nähdä välineellisempänä legitimoin- tistrategiana, sillä sen kautta legitimoidaan tekoja ja päätöksiä sekä niistä saatavia hyötyjä ja etuja. Näiden kahden legitimointistrategian yhteydestä kertoo kuitenkin se, että päätöksestä saatava hyöty ei ole hyöty, mikäli sitä ei moraalisesti koeta hyödyksi. Rationalisoinnin ja moralisoinnin käsitteet ovat toisiinsa sekoittuneet, ja vain pienien vivahteiden avulla ne pystytään erottamaan toisistaan.

Legitimiteettiä voi konstruoida myös tarinankerronnan eli narrativisoinnin avulla (Van Leeuwen 2008; Vaara ym. 2006). Narrativisointi voi tapahtua moraaliopetusten (moral tale) tai varoittavien opetusten (cautionary tale) kautta. Moraaliopetus on toiminnan idealisointiin tai sen arvon korostamiseen liittyvä kertomus, jonka tarina kulkee haasteesta vaikeuksien kautta voittoon. Varoittava opetus taas antaa esimerkin siitä, mitä ei-toivotun toiminnan seurauksena voi tapahtua. Dramaattisessa narrativisoinnissa huomio kiinnitetään siihen, miten asioista kerrotaan ja keitä ovat tarinan voittajat, häviäjät ja sankarit. Samalla nämä tarinat antavat esimerkin hyväksyttävästä ja toivottavasta käytöksestä. Narratiivit eroavat muista legitimointistrategioista siten, että ne ovat yleensä viihdyttäviksi tarkoitettuja ja ne kiinnostavat kuulijaa täten erilaisella tasolla.

Edellä esitettyjen neljän legitimointistrategian lisäksi Vaara ym. (2006) ovat tunnistaneet normalisoinnin omaksi strategiakseen. Myös Van Leeuwen (2008) on viitannut normalisoinnin strategiaan, tosin moralisoinnin alakäsitteenä. Normalisointi tapahtuu viittaamalla normaaliin tai luonnolliseen toimintaan ja käytökseen turvautumalla erilaisiin esikuviin. Normalisoinnin avulla jokin asia pyritään saamaan näyttämään normaaliuden ja tavanomaisuuden avulla legitiimiltä. Esikuvia voidaan etsiä menneestä samanlaisten tapausten ja toimintamallien parista tai tulevista normaaleista ja tavanomaisista tapahtumista (Vaara ym. 2006).

Auktorisoinnin, rationalisoinnin, moralisoinnin, narrativisoinnin ja normalisoinnin legitimointistrategiat esiintyvät usein yhtäaikaisesti ja toisiaan tukien. Kaiken toiminnan perustalla on oltava yleisesti legitiimeiksi koetut arvot, joiden muodostumiseen vaikuttaa jaettu käsitys moraalista. Moralisointistrategia kulkee yhdessä erityisesti rationalisoinnin strategian kanssa, mutta myös auktorisoinnilla, narrativisoinnilla 
sekä normalisoinnilla on oltava moraalisesti hyväksyttävä perusta. Jos auktorisointi ei perustu moraalisesti kestävään pohjaan, ei siihen vetoaminen kasvata organisaation legitimiteettiä. Tällainen tilanne voi muodostua esimerkiksi silloin, jos organisaatio pyrkii legitimoimaan toimiaan tutkimuksella, jonka tiedetään olevan virheellinen tai puolueellinen. Myös narratiivien on oltava moraalisesti kestäviä ja linjassa yleisen arvokäsityksen kanssa, sillä niiden kautta luodaan mielikuvia hyväksyttävästä ja toivottavasta käytöksestä. Normalisointi ja moralisointi eivät myöskään toimi ilman toisiaan, sillä mikäli organisaation toimia legitimoidaan vetoamalla luonnolliseen ja tavanomaiseen toimintaan, on tämä normaalius institutionalisoitunutta ja näin ollen yleisen moraalikäsityksen mukaista.

\section{AINEISTO JA MENETELMÄT}

Tutkimusaineisto koostuu julkisista dokumenteista sekä kohderyhmähaastattelusta. Dokumenttiaineistoon lukeutuvat lainsäädäntöaineisto, valtionhallinnon ja Euroopan Unionin valtiontukiin liittyvät dokumentit sekä sanomalehtiartikkelit, joissa on haastateltu varustamoiden johtoa valtiontuista. Euroopan Unionin ja Suomen valtion lainsäädäntöaineiston keruu oli varsin yksiselitteistä dokumentaation ja aineiston saatavuuden vuoksi. Koska tutkimuksen keskiössä on ajankohtainen valtiontuista käytävä keskustelu, sanomalehtiartikkeleita tutkimukseen valittiin vain vuosilta 2015-2017. Artikkeleiden avulla ei ollut tarkoitus tehdä kattavaa media-analyysia, vaan nostaa esille legitimoivia diskursseja korostavia puheenvuoroja. Sanomalehtiartikkeleista valittiin vain ne, joissa oli varustamoiden edustajien suoria merenkulun tukiin liittyviä puheenvuoroja.

Kohderyhmähaastattelu toteutettiin merenkulun suurimmille tuensaajille, joita ovat matkustajaliikenteessä toimivat varustamot, sekä heidän edunvalvontajärjestönsä edustajalle. Haastatteluun osallistui kuusi edellä mainittujen tahojen edustajaa sekä kolme tutkijaa. Ryhmähaastattelun etuja ovat ryhmädynamiikan hyödyntäminen ja rikkaampi aineisto, joiden lisäksi se on vähemmän yksittäisen tutkijan kysymyksistä riippuvainen (Koskinen ym. 2005). Haastattelun tueksi oli koottu haastattelurunko, johon oli kerätty tärkeimpiä keskus- teltavia aihealueita, mutta lopulta tutkijoiden rooli keskustelun johdattelussa jäi pieneksi. Talouselämän eliittiä haastatellessa onkin varsin normaalia, että erityisen tärkeissä ja arkaluontoisissa kysymyksissä vastaukset ja lähestymistapa ovat ennakolta mietittyjä, eivätkä yrityksen johtoasemissa olevien henkilöiden näkemykset voi olla ristiriidassa oman organisaation toimenpideohjelmien tai arvojen kanssa (Koskinen ym. 2005, 121-122). Tutkimushaastattelu ja dokumenttiaineisto täydentävät toisiaan, ja niiden avulla tutkimukseen sisältyy diskurssianalyysin toteuttamisen kannalta tärkeä kontekstin ja intertekstuaalisuuden tarkastelu. Koska aineistoa on kerätty haastattelussa, mediasta sekä virallisista dokumenteista, muodostuu empiriasta tapaustutkimukselle tyypillinen aineistotriangulaatio.

\section{MERENKULUN VALTIONTUKIA LEGITIMOIVAT DISKURSSIT}

Tässä tutkimuksessa tunnistettuja merenkulun valtiontukia legitimoivia diskursseja ovat ulosliputuksen välttäminen, työllisyyden turvaaminen, huoltovarmuuden ja logistiikan turvaaminen, turismin positiiviset vaikutukset sekä merenkulkusektorin erityispiirteet. Myös muita merenkulun tukia legitimoivia diskursseja on olemassa, mutta tässä tutkimuksessa keskitytään yllä oleviin hallitseviin diskursseihin, jotka esiintyvät useammassa kuin yhdessä aineistolähteessä.

\section{Ulosliputuksen välttäminen}

Eurooppalaisia aluksia on viime vuosikymmenten aikana ulosliputettu huomattavan paljon mukavuuslippuvaltioihin. Näillä tarkoitetaan kolmansien maiden ylläpitämiä alusrekistereitä tai avoimia rekistereitä, joihin varustamot voivat rekisteröidä aluksiaan välttääkseen kotimaan vero- ja palkkakustannukset tai valtion sääntelyn. Tunnettuja mukavuuslippuvaltioita ovat esimerkiksi Bahama, Panama ja Liberia. Hillitäkseen alusten ulosliputusta Euroopan Unioni on antanut poikkeusluvan merenkulkuelinkeinon tukemiselle julkaisemalla vuonna 2004 merenkulun tukemisen suuntaviivat. Euroopan Unionin mukaan paras ratkaisu tilanteeseen on luoda sellaiset olosuhteet, jotka 
mahdollistavat eurooppalaisten varustamoiden kilpailukyvyn mukavuuslippumaiden kanssa (Euroopan komissio 2004.)

Euroopan Unionin suuntaviivoissa käytetään moralisoinnin ja rationalisoinnin legitimointistrategioita. Moralisoinnin strategian avulla arvostellaan mukavuuslippumaiden ylläpitämiä veroparatiiseja sekä piittaamattomuutta kansainvälisistä laeista. Rationalisoinnin strategian avulla vedotaan eurooppalaisten alusten puutteelliseen kilpailukykyyn ja todetaan, että ilman tukimekanismien käyttöönottoa varustamoiden taloudellinen houkutus siirtää alukset mukavuuslippumaihin kasvaisi liian suureksi.

Euroopan aluskanta on 1970-luvulta lähtien joutunut kilpailemaan sellaisten kolmansiin maihin rekisteröityjen alusten kanssa, jotka eivät piittaa kansainvälisistä työmarkkina- ja turvallisuussäännöistä. Yhteisön jäsenvaltioiden lippujen alla purjehtivien alusten puutteelliseen kilpailukykyyn alettiin kiinnittää huomiota 1980-luvun lopulla. (Euroopan komissio 2004, 1.)

Euroopan Unionin ulosliputusaiheisessa diskurssissa legitimiteetin tyyppi on moraalista legitimiteettiä. Moraalinen legitimiteetti ei keskity toiminnasta saataviin hyötyihin tai omien etujen tavoitteluun, vaan siihen, että toiminta edistää moraalisesti oikeita asioita (Suchman 1995). Euroopan Unioni legitimoi merenkulun tukemisen poikkeuslupaa sillä, että Unioni toimii moraalisesti oikein, kun se antaa jäsenvaltioilleen oikeuden tukea merenkulkusektoreitaan mukavuuslippuvaltioita vastaan. Euroopan Unioni korostaa näin tukevansa eurooppalaisia veroja maksavia ja sääntöjä noudattavia varustamoita.

Suomessa myös matkustaja-alukset pääsivät henkilöstökustannuksia pienentävän miehistökustannustuen piiriin vuonna 2002. Suomalaisessa lainsäädännössä suurimpana uhkana merenkulkusektorille ei pidetä mukavuuslippumaita, vaan Itämeren alueen naapurimaita. Syynä tukien laajentamiselle oli kilpailutilanteen kiristyminen, mikä johtui Itämeren alueen maissa toteutetuista matkustaja-alussektoreita koskevista tukitoimenpiteistä.

Merenkulun tukien myöntämistä matkustajaalusliikenteeseen legitimoidaan auktorisoinnin ja rationalisoinnin strategioiden avulla. Auktorisoinnin avulla tuilla esitetään olevan ikään kuin korkeamman tason hyväksyntä. Auktoriteetteina ovat suomalaisen merenkulun kilpailijamaat sekä Euroopan Unioni. Suomalaisessa lainsäädäntöaineistossa todetaan, että ilman tukimekanismia varustamot siirtäisivät toimintansa muihin tukia tarjoaviin maihin.

Esityksellä pystytään vastaamaan siihen kilpailutilanteen kiristymiseen, mikä on aiheutunut Pohjoismaissa ja muissa kilpailijamaissamme sekä erityisesti Ruotsissa hiljattain toteutettujen, myös matkustaja-alussektoria koskevien tukitoimenpiteitten seurauksena... Mikäli Suomessa ei ryhdytä matkustaja-alusten kustannuksia alentaviin toimenpiteisiin, on odotettavissa, että Suomen lipun alla olevat matkustaja-alukset siirretään pois Suomen alusrekisteristä muiden kilpailukykyisempien lippujen alle. (HE 210/2002.)

Rationalisoinnin strategia esiintyy vedottaessa hyötyihin, joita merenkulun toimijoista on suomalaiselle yhteiskunnalle. Koska yhteiskunnan hyödyttäminen on myös moraalisesti hyvä asia, voidaan rationalisoinnin strategian ohella $\mathrm{ky}$ seessä nähdä olevan myös moralisoinnin strategian käyttö.

Ulosliputuksen jälkeen kaikki työnantajan maksamat verot ja maksut jäävät yhteiskunnalta saamatta. Nettopalkkausta vastaavassa tukijärjestelmässä ne joko palautetaan työnantajalle tai työnantaja vapautuu niiden maksamisesta, joten tältä osin tilanne on valtion budjettitalouden kannalta yhdenmukainen. Ulosliputuksen yhteydessä kuitenkin menetetään eräitä sellaisia eriä, jotka tukijärjestelmässä koituvat normaalisti suomalaisen yhteiskunnan hyväksi. Tärkeimmät näistä ovat työntekijän palkastaan maksamat maksut Merimieseläkekassalle sekä sairausvakuutusmaksu ja työttömyysvakuutusmaksu. (HE 72/2004.)

Legitimiteettityypiltään suomalainen lainsäädäntö perustuu enemmän pragmaattiseen kuin moraaliseen legitimiteettiin. Pragmaattisella legitimiteetillä tarkoitetaan vaihtokauppaan ja sen tuottamiin hyötyihin perustuvaa legitimi- 
teettiä. Merenkulun vaihtokaupassa varustamot vastaanottavat valtiontukia ja pitävät aluksensa Suomen lipun alla, mistä valtio hyötyy esimerkiksi verotulojen ja sosiaaliturvamaksujen muodossa.

Ulosliputuskeskustelu pohjautuu kansallisiin etuihin liittyvälle diskurssille, jossa oman maan etu asetetaan etusijalle muihin toimijoihin nähden. Globalisaatio nähdään eurooppalaisten etujen vastaisina, ja protektionismi ainoana tilanteeseen sopivana ratkaisuna. Sekä Euroopan Unionin että Suomen merenkulun tukipolitiikkaa voidaan kuvata protektionistiseksi, mutta protektionismin tasot eroavat toisistaan. Euroopan Unionin suurin huolenaihe on laivojen ulosliputus Unionin ulkopuolelle, kun taas suomalaisessa lainsäädännössä ollaan eniten huolissaan ulosliputuksista Suomen naapurimaihin, erityisesti Ruotsiin.

\section{Työllisyyden turvaaminen}

Edellä esitetty mukavuuslippumaihin kohdistuva ulosliputusuhka liittyy pääosin rahtialuksiin. Euroopan Unionin suuntaviivoissa (2004) todetaan, että Unionin jäsenmaiden kansalaisten työllisyyden turvaaminen on merkittävin syy sille, että merenkulun valtiontuet on säädetty koskemaan myös Unionin sisäistä matkustaja-alusliikennettä. Myös suomalaisessa lainsäädännössä työllisyyden turvaaminen on yksi keskeisimmistä tukia puoltavista argumenteista.

Suomalaisessa työllisyysdiskurssissa käytetään erityisesti hyötyihin vetoavaa rationalisoinnin legitimointistrategiaa. Tässä kontekstissa hyödyt liittyvät työllisyyteen, osaamiseen sekä yleisesti mereen liittyvien toimintojen arvonlisäykseen investointien ja sektorin kasvun kautta. Rationalisoinnin kautta pyritään osoittamaan, että valtiontukien vastineeksi tuotetaan hyötyjä myös muille kuin merellä työskenteleville henkilöille.

Tuen arvioidaan vaikuttavan suotuisasti suomalaisten merenkulkijoiden työllisyyteen... Suomen ulkomaanliikenteen kauppa-alusluetteloon kuuluvilla matkustaja-aluksilla tehtiin vuonna 2005 yhteensä 3750 henkilötyövuotta josta muodostunut merityötulo oli 131 miljoonaa euroa. Vaikutus koko meriklusteriin on moninkertainen... On kuitenkin selvää, että ainakin lyhytaikaisesti lippusiirrosta aiheutuu yhteiskunnalle kustannuksia myös lisääntyvän työttömyyden muodossa. (HE 226/2006.)

Suomalaisten varustamoiden legitimointistrategioina työllisyysdiskurssissa ovat narrativisointi, rationalisointi ja auktorisointi. Varustamot käyttävät narrativisoinnin legitimointistrategiaa luomalla varoittavan tarinan siitä, mitä ei-toivotun toiminnan seurauksena voi tapahtua. Narratiivissa korostetaan sitä, kuinka ei-toivotun tapahtuman vuoksi jokin toinen valtio Suomen sijaan saisi varustamoiden verotulot ja toiminnan hyödyt. Hyötyihin vedottaessa voidaan huomata rationalisoinnin ja moralisoinnin legitimointistrategioiden tukevan narrativisointia.

Viking Line pohtii vakavasti Ruotsiin muuttamista, jos Suomen hallitus leikkaa 20 miljoonaa euroa matkustaja-alustuesta. Yhtiön toimitusjohtaja Jan Hanses kertoo, että leikkaus heikentäisi kannattavuutta ja vaarantaisi työpaikat. "Ruotsiin siirtyminen olisi todennäköinen toimenpide, ja verot maksettaisiin sen jälkeen Ruotsiin." (Helsingin Sanomat 12.6.2015.)

Varustamot käyttävät auktorisoinnin strategiaa vetoamalla yrityksen kannattavuuteen ja pörssiyhtiön lakisääteisiin velvollisuuksiin. Matkustaja-autolauttavarustamot ovat yksityisiä voittoa tavoittelevia yrityksiä, joiden tulee tuottaa voittoa osakkeenomistajilleen. Valtiontukien poistaminen aiheuttaisi huomattavan loven varustamoiden rahoitukseen, jolloin ulosliputus muodostuisi ainoaksi taloudellisesti järkeväksi ratkaisuksi.

"Lipunvaihtaminen olisi huonoimman vaihtoehdon skenaario, mutta silti mahdollinen." Tiedotusjohtajan mukaan ulosliputtamiseen turvautuminen johtuisi puhtaasti taloudellisista realiteeteista. "Viking Line on pörssiyhtiö. Meidän pitää pystyä takaamaan työtä henkilökunnallemme ja kannattavuutta osakkeenomistajille... Valtio säästäisi 20 miljoonaa, mutta työntekijämme maksaisivat verot Ruotsiin. Mikä hyöty sillä saavutettaisiin" (Taloussanomat 12.6.2015.) 
Työllisyyden turvaamisen diskurssi on legitimiteettityypiltään pragmaattista vaihtokauppalegitimiteettiä, sillä sen mukaan tukemalla merenkulkusektoria valtio saa vaihtokaupassa työpaikkoja ja elinvoimaisen merenkulkusektorin. Työllisyyskeskustelussa voidaan katsoa vedottavan myös moraaliseen legitimiteettityyppiin, sillä suomalaisessa yhteiskunnassa hyvinvointivaltion katsotaan olevan osittain vastuussa työpaikkojen säilymisestä. Matkustajamerenkulun tukemisen voidaan katsoa täten edistävän moraalisesti hyväksi koettuja asioita.

Ideologisesta näkökulmasta pörssiyhtiön kannattavuuden takaaminen on varustamoille tärkeämpi tavoite kuin suomalaisten työpaikkojen säilyttäminen. Varustamot ovat valmiita ulosliputtamaan aluksensa ja vaihtamaan kotimaisesta ulkomaalaiseen työvoimaan, mikäli niiden valtiontuet poistettaisiin. Vaikka ulosliputustilanteessa varustamot eivät kokisi suomalaisten työpaikkojen tukemista vastuukseen, käyttävät ne kuitenkin suomalaisten työllistämiseen liittyviä argumentteja silloin, kun ne haluavat puolustaa valtiontukien olemassaoloa ja järjestelmän nykytilaa.

\section{Huoltovarmuuden ja logistiikan turvaaminen}

Huoltovarmuus on merkittävä valtiontukia legitimoiva tekijä, sillä Suomi on maantieteelliseltä asemaltaan vaikeasti saavutettavissa, ja sen ulkomaankauppa on pitkälti riippuvainen meriteitse tapahtuvista kuljetuksista. Suomen valtio käyttää huoltovarmuuden turvaamiseen liittyvässä diskurssissa rationalisoinnin ja moralisoinnin strategioita. Rationalisoinnin strategian keinoin esitetään tarve suomalaiselle laivastolle ja pätevälle miehistölle, kun taas moralisoinnin strategia esiintyy legitimoitaessa valtiontukien olemassaoloa yhteiskunnan toimivuuden kannalta.

Meriliikenteen suuntaviivojen perusteella maksetuilla tuilla on merkitystä myös huoltovarmuuden näkökulmasta. Suomen maantieteellinen pohjoinen ja suurilta kauppaväyliltä syrjäinen sijainti merkitsee, että alusliikenne, nimenomaan Itämeren merikuljetukset, kaikissa talouden olosuhteissa ja myös talviaikaan on yhteiskunnan toiminnan kannalta ratkaisevan tärkeää. (Euroopan Unionin konsultaatio 2012, 12-13.)

Varustamot legitimoivat valtiontukien olemassaoloa nostamalla esiin roolinsa huoltovarmuuteen turvaamisessa. Varustamot käyttävät auktorisoinnin strategiaa vetoamalla Huoltovarmuuskeskukseen sekä huoltovarmuuteen liittyvään salassa pidettävään tietoon. Jo tieto siitä, että matkustaja-aluksille on nimetty rooli huoltovarmuuden turvaamisessa, riittää auktorisointiin huoltovarmuuden nimissä.

Matkustaja-autolautoilla on nimetty rooli, mi$k a ̈$ ei ole julkinen. Rooli on vieläkin suurempi kuin mitä esimerkiksi Ruotsissa, koska Suomi on käytännössä saari ja maantieteellinen asema on niin erilainen. Suomi on saari, ja tämän kaltainen sijainti tarkoittaa sitä, että Suomi tarvitsee oman laivaston ja oman telakkateollisuuden. (Haastateltava 1)

Varustamot korostavat logististen toimintojensa olevan yhteiskuntaa hyödyttävää toimintaa. Moralisoinnin ja rationalisoinnin strategioiden avulla vedotaan toiminnasta koituvaan yhteiseen hyvään. Vaikka varustamot eivät ole julkisia toimijoita, pyrkivät niiden edustajat legitimointipuheessaan korostamaan toimintansa yhteiskunnallista hyödyllisyyttä.

Emme käytä termiä matkustajamerenkulku, vaan aikataulutettu linjaliikenne osana yhteiskuntaa palvelevaa logistista ketjua... Laivojen aikataulut pitävät, ne evät myöhästele ja niiden kautta logistiikkaa saadaan luotettavasti perille. Suomessa tavaroiden saatavuus ja hinta olisi erilaiset, jos linjaliikennettä ei olisi. (Haastateltava 3)

Huoltovarmuuden ja logistiikan turvaamisen diskurssissa legitimiteetti perustuu pragmaattiseen vaihtokauppalegitimiteettiin, mutta toiminnan mahdollista ulosliputusta ja siitä seuraavaa Suomen huoltovarmuuden heikentymistä ei korosteta yhtä paljon kuin ylempänä kuvatuissa diskursseissa. Huoltovarmuuteen liittyvässä keskustelussa voidaan tunnistaa kognitiivinen 
legitimiteettityyppi. Kognitiivinen legitimiteetti tarkoittaa organisaation olemassaolon ja yhteiskunnallisen tarpeellisuuden syvällistä ja myös tiedostamatonta hyväksyntää (Suchman 1995). Yhteiskunnan auttamisen kriisitilanteissa voidaan katsoa olevan jokseenkin itsestäänselvyys, eikä ulosliputusuhkauksia esitetä huoltovarmuuskeskustelun piirissä.

\section{Turismin edistäminen}

Varustamotoiminnan työllistävyydestä ja yhteiskuntaa hyödyttävistä toiminnan muodoista huolimatta turismin ja viihdepalveluiden tarjoaminen on merkittävä osa varustamoiden liiketoimintaa. Suomalaisesta lainsäädännöstä mainintaa tuen osittaisesta kohdentumisesta matkailuun ja viihdepalveluihin ei löydy. Varustamot taas legitimoivat tuen kohdentumisen viihde- ja matkailupalveluihin vetoamalla alusten miehitykseen liittyvään lainsäädäntöön ja Suomeen suuntautuvaan turismin edistämiseen.

Varustamot käyttävät auktorisoinnin strategiaa legitimoidessaan valtiontukien kohdentumista asiakaspalveluhenkilökuntaan. Varustamot vetoavat aluksen miehitystä säätelevään lakiin, joka velvoittaa alukselle tietyn määrän esimerkiksi ruoanlaittoon ja siivouspalveluihin keskittyvää henkilökuntaa. Varustamot käyttävät myös moralisoinnin strategiaa korostaessaan asiakaspalvelun parissa työskentelevien henkilöiden tehtäviä laivan turvallisuusorganisaatiossa.

Taloushenkilökunta kuuluu laivan turvallisuusjärjestelmään, heillä on oma tehtävänsä laivan turvallisuusorganisaatiossa. Laivan turvallisuusjärjestelmästä putoaa pois ainoastaan ulkopuoliset artistit, joille ei ole annettu tehtävää laivan organisaatiossa. (Haastateltava 5)

Valtiontukia legitimoidaan myös korostamalla turismin positiivisia vaikutuksia suomalaiselle elinkeinoelämälle. Päivittäinen linjaliikenne Tukholmaan ja Tallinnaan antaa suomalaisille mahdollisuuden edulliseen ulkomaanmatkailuun, mutta houkuttelee turisteja Pohjoismaihin myös muualta maailmasta.
Suomalaiset matkustajavarustamot markkinoivat Suomea matkailun kohdemaana joka päivä vuoden ympäri Pohjoismaissa, Euroopassa ja Baltian maissa. Tätä Suomen markkinointityötä varustamot ovat tehneet vuosikymmeniä siitä alkaen kun Suomen matkustaja-autolauttaliikenne alkoi vuonna 1959. (Suomen Varustamot Ry:n tiedonanto)

Varustamot käyttävät rationalisoinnin strategiaa argumentoidessaan Suomeen suuntautuvan matkailun hyödyttävän suomalaista elinkeinoelämää ja maan koko matkailusektoria taloudellisesti. Legitimointistrategiana voidaan nähdä olevan myös moralisoinnin strategia, sillä varustamot korostavat edistävänsä yhteistä hyvää mahdollistaessaan ulkomaisten turistien saapumisen Suomeen.

Nämä varustamot markkinoivat Suomea Euroopassa ja Aasiassa matkailumaana joka päivä. Varustamojen yhteisön ja hotellielinkeinon tulisi miettiä yhteisiä etuja. Varustamot edustavat tietämystä miten markkinoida Suomea enemmän kuin jokin yksittäinen hotelli. Yhteistyö varustamoiden ja hotellielinkeinon kanssa Suomessa voisi tuottaa paljonkin yhteisiä etuja. (Haastateltava 1)

Turismin edistämiseen keskittyvän diskurssin legitimiteettityyppi on pragmaattinen legitimiteetti. Varustamot kääntävät asiakaspalveluhenkilökuntaan kohdentuvan valtiontuen suomalaista elinkeinoelämää hyödyttäväksi asiaksi. Tuensaajat pyrkivät tässä diskurssissa osoittamaan, että merenkulun saamat valtiontuet tuovat Suomeen moninkertaisesti enemmän tuottoja.

\section{EU-maiden yhdenmukaisen toiminnan takaaminen}

Viimeisimpänä valtiontukien olemassaoloa legitimoivana diskurssina voidaan tunnistaa vetoaminen EU-maiden yhdenmukaisen toiminnan takaamiseen.

Varustamot legitimoivat valtiontukien olemassaoloa varoittavan narratiivin avulla. Narratiivin mukaan Suomen katsottaisiin toimivan Euroopan Unionin suositusten vastaisesti, mikäli se päättäisi karsia tukien määrää tai lak- 
kauttaa ne kokonaan. Tässä ulkopuolisuuden pelkoon vetoavassa narratiivissa käytetään normalisoinnin strategiaa osoittamaan suomalaisen merenkulkusektorin kilpailijamaiden toimivan normaalilla ja suotavalla tavalla, josta poikkeamisella olisi Suomelle kohtalokkaita seurauksia.

Tutkimukset osoittavat, että Euroopan Unionin laajuisesti tuet ovat toimineet hyvin. Lopputuloksena on se, että EU:ssa ei ole poliittista tahtoa lopettaa tukemista. Haluaako

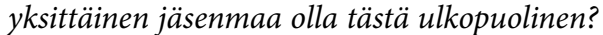
Tämä johtaisi siihen, että samat laivat vaihtaisivat vain eri jäsenmaihin. Tällöin asia olisi täysin plus miinus nolla valtion kannalta. (Haastateltava 2)

Suomalaisten varustamoiden mielestä Euroopan Unionin suuntaviivat toimivat hyvin myös Unionin sisäisessä matkustajaliikenteessä eikä tukikilpailua jäsenmaiden välillä ole. Tämä kommentti voidaan nähdä ristiriitaisena ottaen huomioon ulosliputuksen estämiseen ja työllisyyden turvaamiseen liittyvät diskurssit, joissa ulosliputuksen uhka luo perustan vaihtokaupalle. Varustamot pyrkivät luomaan Euroopan Unionin suuntaviivoista kaikkia toimijoita hyödyntävän mielikuvan, ja tukijärjestelmää pidetään moraalisesti oikeana, koska sen väitetään takaavan tasapuolisuuden maiden kesken.

EU: $n$ suuntaviivat itse asiassa varmistavat sen, ettei tukikilpailua synny. Ne antavat jäsenmaille mahdollisuuden tukea omaa merenkulkusektoriaan. Kun kaikille on yhteiset säännöt, ei yksi toimija voi asettaa muita parempaa tukijärjestelmää. Tämä on eurooppalainen etu. (Haastateltava 2)

Mahdollisesta tukikilpailusta huolimatta sekä varustamot että valtio haluavat korostaa tukien moraalista hyväksyttävyyttä. Suomen valtio myöntää tukikilpailun mahdollisuuden mutta legitimoi valtiontukijärjestelmän olemassaoloa sillä, että pahimmillaankin tukikilpailu olisi pientä ja kontrolloitua, ja se olisi joka tapauksessa siedettävämpää kuin merenkulkusektorin jättäminen kokonaan ilman valtiontukia. Tällä normalisoinnin strategiaan perustuvalla legitimointipuheella pyritään luomaan tuille moraalisesti hyväksyttävä perusta.
Tukikilpailu suuntaviivojen rajoissa on mahdollista jäsenvaltioiden valitessa itsenäisest $i$ ne toimenpiteet, joilla tukea merenkulkualalle kansallisesti myönnetään. Kuitenkin yhteiset periaatteet tuen myöntämiselle ja sen enimmäistason määrittäminen vähentävät merkittävästi mahdollista tukikilpailua jäsenvaltioiden kesken. (Euroopan Unionin konsultaatio 2012, 15-16.)

Viimeisimpänä strategiana varustamot käyttävät normalisointia nimeämällä valtiontuen palautukseksi. Suomalaisessa järjestelmässä varustamot maksavat työntekijöiden verot ja palkan sivukulut normaalilla tavalla, mutta saavat saman summan valtiolta takaisin "palautuksena". Varustamot pyrkivät luomaan mielikuvan, jossa miehistökustannustukea ei käsitettäisi valtiontueksi vaan veroista vapautuminen olisi merenkulkusektorin itsestään selvä oikeus: "Kyse on palautuksesta. Suomen miehistökustannustuki on omiaan aiheuttamaan väärinkäsityksiä. Muualla tätä ei edes kutsuta tueksi. Ruotsissa tämä on palautus." (Haastateltava 5.) Myös mediassa varustamot ovat pyrkineet luomaan mielikuvan palautuksesta normalisoinnin strategian avuin: "Tässä on väärinkäsitys. Varustamolle palautettavat merimiesten ennakonpidätykset ja sosiaaliturvamaksut eivät ole yritystukea, vaan ne ovat tukea suomalaisille merityöntekijöille" (Kauppalehti 25.1.2017).

Sektorin erityispiirteisiin liittyvässä diskurssissa vedotaan moraaliseen legitimiteettityyppiin. Moraaliin perustuvan legitimiteetin avulla on tarkoituksena päästä tilanteeseen, jossa sektorin etuoikeudet tunnustettaisiin. Tämän kautta sektorin tukeminen valtiontukien avulla koettaisiin yleisesti hyväksyttäväksi ja lopulta itsestäänselvyydeksi. Merenkulun toimijoiden tarkoituksena on luoda kuva hyväksyttävästä tukijärjestelmästä, jolla on rationaaliset perusteet.

\section{PÄÄTELMÄT}

Tämän tutkimuksen tarkoituksena on ollut tutkia merenkulun valtiontukijärjestelmää legitimiteetin näkökulmasta. Tutkimuksessa haluttiin ymmärtää, miten mielikuva valtiontuen yleisestä hyväksyttävyydestä eli legitimiteetistä rakennetaan ja millaiselle oikeutukselle merenkulun tukemisen katsotaan perustuvan. Merenkulun 
valtiontukijärjestelmän legitimiteettiä analysoitiin puheen ja tekstin tasolta kriittisen diskurssianalyysin keinoin, ja sen avulla pystyttiin kiinnittämään huomio esimerkiksi itsestäänselvyyksiin ja valtarakenteisiin.

Tutkimuksessa nousi esille viisi merenkulun valtiontukien olemassaoloa legitimoivaa diskurssia, joita ovat ulosliputuksen estäminen, työllisyyden turvaaminen, huoltovarmuuden ja logistiikan turvaaminen, turismin edistäminen sekä EU-maiden yhdenmukaisen toiminnan takaaminen. Jokaisesta diskurssista löydettiin yksi tai useampi legitimiteettiä rakentava strategia. Valtionhallinnon ja Euroopan Unionin dokumenteissa käytettiin pääasiassa rationalisointia ja moralisointia, kun taas varustamot käyttivät tämän lisäksi useasti myös auktorisointia. Varustamot käyttivät legitimointistrategioina myös narrativisointia kertomalla varoittavia esimerkkejä ja normalisointia vedotessaan muiden maiden valtiontukijärjestelmiin. Samojen diskurssien sisällä käytettiin useita eri legitimointistrategioita, esimerkiksi rationalisoinnin, moralisoinnin ja auktorisoinnin legitimointistrategiat esiintyivät tässä tutkimuksessa useassa tapauksessa yhdessä.

Tutkimusaineistosta tunnistettiin myös eri legitimiteettityyppejä. Vaihtokauppaan liittyvä pragmaattinen legitimiteetti tunnistettiin ulosliputuksen estämiseen, työllisyyden turvaamiseen, huoltovarmuuden ja logistiikan turvaamiseen sekä turismin edistämiseen liittyvissä diskursseissa. Vaihtokauppalegitimiteetissä vastakkain ovat Suomen valtion myöntämät valtiontuet ja varustamoiden suomalaisessa rekisterissä olevat alukset. Kun varustamoille annetaan valtiontukia, ne jatkavat yhteiskunnan kannalta hyödyllisten toimintojen ylläpitoa Suomen lipun alla. Koska varustamot pystyisivät hyvin nopealla aikataululla siirtämään toimintonsa johonkin muuhun maahan, vaihtokaupan edut Suomen valtiolle konkretisoituvat hyvin selkeästi.

Myös moraalinen legitimiteettityyppi pystyttiin tunnistamaan useasta valtiontukia legitimoivasta diskurssista. Työllisyyteen, huoltovarmuuteen ja turismiin liittyvissä diskursseissa valtiontukien legitimiteetti perustuu pragmaattisen legitimiteetin lisäksi myös lopputuloksen legitimiteettiin, joka merkitsee tässä yhteydessä positiivisia ja toivottavia yhteiskunnallisia vai- kutuksia kuten työllisyyttä, logistiikan toimivuutta sekä Suomeen suuntautuvan turismin lisääntymistä. Ulosliputuksen välttämiseen sekä EU-maiden yhdenmukaisen toiminnan takaamiseen liittyvissä diskursseissa valtiontukien korostettiin olevan ainoa legitiimi tapa, jolla joukkoulosliputukset mukavuuslippumaihin voidaan estää ja merenkulkusektoria tukea. Myös kognitiivisen legitimiteetin olemassaolo pystyttiin tunnistamaan huoltovarmuuskeskustelussa, jossa varustamot eivät niinkään korostaneet pragmaattista omien hyötyjen tavoittelua tai nostaneet esiin ulosliputusmahdollisuutta, vaan pitivät huoltovarmuuden turvaamista pikemminkin itsestäänselvyytenä kuin vaihtokaupan välineenä.

Niin kuin rationalisoinnin ja moralisoinnin legitimointistrategiat, myös pragmaattinen vaihtokauppalegitimiteetti ja moraalinen lopputuloksen legitimiteetti vaikuttavat liittyvän toisiinsa useassa kohtaa tätä tutkimusta. Varustamot mielellään korostavat moraalista legitimiteettiään ja sitä hyvää, mitä niiden toiminnasta aiheutuu, mutta moraalisten diskurssien takaa kuultaa omien etujen tavoittelu ja selkeä tieto siitä, että mikäli varustamoiden etuja karsitaan, ne pystyvät helposti siirtämään toimintansa jonkin toisen valtion lipun alle.

Jokaiselle legitimoivalle diskurssille oli tunnistettavissa ideologinen tausta, jota vasten legitimiteetti rakentui. Ulosliputuksen estämisen diskurssissa, jossa kuului erityisesti Euroopan Unionin ja Suomen valtion ääni, korostettiin protektionististen toimien tarpeellisuutta mukavuuslippumaiden uhkaan vastaamisen välineenä. Sen sijaan työllisyyden turvaamisen diskurssissa tunnistettiin mielenkiintoinen kapitalististen ja nationalististen arvojen vuorottelu. Sekä valtio että varustamot tunnistivat varustamoiden taloudelliset intressit: mikäli valtiontukien määrää pienennettäisiin Suomessa, varustamot vaihtaisivat herkästi jonkin toisen valtion alusrekisteriin ja hakisivat vastaavat tuet sieltä. Nationalistiset arvot tulivat esille varustamoiden korostaessa työllistävänsä mielellään suomalaisia ja maksavansa suomalaisesta miehistöstä enemmän kuin esimerkiksi virolaisesta. Työllisyyskeskustelussa taloudelliset intressit ja kapitalistiset arvot olivat kuitenkin lopulta suomalaisten työllistämistä ja nationalistisia arvoja 
korkeammalla, sillä mikäli merenkulun valtiontuista leikattaisiin, varustamot kokisivat ainoana vaihtoehtona ulosliputuksen.

Institutionaalisen teorian piirissä legitimiteetin nähdään olevan organisaation elinehto. Samalla tavalla tässä tutkimuksessa voidaan katsoa, että valtiontukien legitimiteetti eli niiden yleinen hyväksyttävyys on ehto niiden olemassaololle ja jatkuvuudelle. Merenkulun valtiontuen legitiimistä asemasta Euroopan Unionissa ja Suomessa kertoo se, että tukimekanismit ovat olleet jo pitkään osa valtion talousarviota eikä tämänhetkisten tietojen mukaan niiden jatkuvuus ole uhattuna. Sen sijaan muualla yhteiskunnassa sekä eri poliittisten ryhmittymien keskuudessa tuilla ei voida katsoa olevan ainakaan itsestäänselvyyden asemaa, sillä aika ajoin tukien tarpeellisuus nostetaan esille eduskunnassa valtion talousarvosta päätettäessä tai edunvalvontaliitot, kansalaisyhteiskunnan jäsenet tai media nostavat esiin tukien epäkohtia. Yhteenvetona voidaankin todeta, että merenkulun valtiontuet eivät ole saavuttaneet itsestäänselvyyden asemaa Suomessa mutta niillä on legitiimi asema tärkeimpien niistä päättävien sidosryhmien piirissä, mikä varmistaa merenkulkusektorin tukemisen pysyvyyden ja jatkuvuuden.

Tutkimusta rajoittaa se, että kyseessä on kahden tutkijan muodostama tulkinta legitimoinnin välineistä sekä tuen koetusta oikeutuksesta. Jo legitimiteetin teoreettisessa määritelmässä huomioidaan legitimiteetin olevan objektiivista

\section{LÄHTEET}

Euroopan komissio (2004). Komission tiedonanto C(2004)43 - Yhteisön suuntaviivat meriliikenteen valtiontuelle. Bryssel 17.1.2004. Viitattu 27.11.2016.

Euroopan Unionin konsultaatio (2012). Meriliikenteen valtiontukia koskevien yhteisön suuntaviivojen tarkistus. Viitattu 25.5.2017.

Fairclough, Norman (1992). Discourse and text: linguistic and intertextual analysis within discourse analysis. Discourse \& Society, 3(2), 193-217.

Fairclough, Norman (2003). Analysing Discourse: Textual Analysis for Social Research. London: Routledge.

Gronau, Jennifer \& Schmidtke, Henning (2016). The quest for legitimacy in world politics - in- mutta muodostuvan yksilöiden subjektiivisten kokemusten pohjalta. Myös kriittisessä diskurssianalyysissa tarvittavien kontekstien ja yhteiskunnan makrodiskurssien tuntemuksessa voi olla hyvinkin paljon eroja tutkijoiden välillä. Samoin diskurssianalyysin yhteydessä on otettava huomioon, että tutkijan toimintaedellytyksiin vaikuttaa jossain määrin myös hänen suhteensa tutkittavaan ilmiöön.

Legitimiteettitutkimusta voidaan hyvin soveltaa muidenkin politisoituneiden valtiontukien aihepiiriin. Erityisesti ympäristön kannalta haitallisten energiamuotojen valtiontuista voisi tunnistaa mielenkiintoista ideologioiden kautta tapahtuvaa legitimointia. Mielenkiintoisia jatkotutkimuksen aiheita voisivat olla suomalaisten valtiontukien ideologiaperustan syvällisempi tutkiminen tai valtiontukien legitimiteetin korjaaminen legitimiteettikriisin jälkeen.

\section{VIITTEET}

1 Huoltovarmuuskeskuksen (2019) mukaan huoltovarmuudella tarkoitetaan huoltovarmuudella tarkoitetaan "kykyä sellaisten yhteiskunnan taloudellisten perustoimintojen ylläpitämiseen, jotka ovat välttämättömiä väestön elinmahdollisuuksien, yhteiskunnan toimivuuden ja turvallisuuden sekä maanpuolustuksen materiaalisten edellytysten turvaamiseksi vakavissa häiriöissä ja poikkeusoloissa”.

ternational institutions' legitimation strategies. Review of International Studies, 42, 535-557.

Hallituksen esitys eduskunnalle laiksi ulkomaanliikenteen kauppa-alusluettelosta annetun lain muuttamisesta ja väliaikaisesta muuttamisesta $(226 / 2006)$

Hallituksen esitys eduskunnalle laiksi ulkomaanliikenteen kauppa-alusluettelosta annetun lain muuttamisesta (72/2004)

Hallituksen esitys eduskunnalle laiksi ulkomaanliikenteen kauppa-alusluettelosta annetun lain 1 ja 4 §:n muuttamisesta (210/2002)

Huoltovarmuuskeskus (2019). https://www.huoltovarmuuskeskus.fi/sanasto/\#h. Haettu 28.2.2019.

Laki taloudelliseen toimintaan myönnettävän tuen yleisistä edellytyksistä 429/2016. 
Joutsenvirta, Maria \& Vaara, Eero (2015). Legitimacy struggles and political corporate social responsibility in international settings: A comparative discursive analysis of a contested investment in Latin America. Organization Studies, 36(6), 741-777.

Koski, Heli \& Ylä-Anttila, Pekka (2011). Yritystukien vaikuttavuus: tutkimushankkeen yhteenveto ja johtopäätökset. ETLA. TEM raportteja $7 / 2011$

Koskinen, Ilkka \& Alasuutari, Pertti \& Peltonen, Tuomo (2005). Laadulliset menetelmät kauppatieteissä. Tampere: Vastapaino.

Lehto, Katriina \& Karppinen, Ari \& Oulasvirta, Lasse \& Saarijärvi, Hannu (2017). Merenkulun tuet - arvio henkilökuljetuksiin kohdistuvista valtiontuista. Erillisjulkaisu. Tampereen yliopisto.

Rauhanen, Timo \& Grönberg, Sami \& Harju, Jarkko \& Matikka, Tuomas (2015). Yritystukien arviointi ja vaikuttavuus. Helsinki: Valtioneuvoston selvitys- ja tutkimustoiminnan julkaisusarja.

Reshef, Yonatan \& Keim, Charles (2014). Bad Time Stories: Government-union Conflicts and the Rhetoric of Legitimation Strategies. Toronto: University of Toronto Press.
Suchman, Mark (1995). Managing legitimacy: Strategic and institutional approaches. Academy of Management Review, 20(3), 571-610.

Tilastokeskus (2017). Suorien tukien määrä kääntyi laskuun. Viitattu 2.3.2017.

Vaara, Eero \& Tienari, Janne \& Laurila, Juha (2006). Pulp and paper fiction: On the discursive legitimation of global industrial restructuring. Organization Studies, 27(6), 789-813.

Van Leeuwen, Theo (2008). Discourse and Practice. New tools for Critical Discourse Analysis. New York: Oxford University Press.

Van Leeuwen, Theo \& Wodak, Ruth (1999). Legitimizing immigration control: A discoursehistorical analysis. Discourse Studies, 1(1), 83118.

VTV (2013). Merenkulun tukeminen. Esiselvitysraportti. Helsinki: Valtiontalouden tarkastusvirasto. Tuloksellisuustarkastus.

VTV (2015). Merenkulun tuet -tarkastuksen päättäminen. Helsinki: Valtiontalouden tarkastusvirasto. Tuloksellisuustarkastus.

Yle (2015). MOT-ohjelman yritystukiaineisto 2010-2014. Yleisradio. Viitattu 29.11.2016. 